\title{
Stages of Cr, Zn, Cu, Si, Ag, and Al Nucleation under Quasi-equilibrium Condensates of Ion-sputtered Atoms
}

\author{
A.S. Kornyushchenko*, Yu.O. Kosminska, S.T. Shevchenko, V.V. Natalich, V.I. Perekrestov \\ Sumy State University, 2, Rymsky-Korsakov St., 40007 Sumy, Ukraine
}

(Received 25 October 2020; revised manuscript received 15 April 2021; published online 20 April 2021)

\begin{abstract}
The paper represents the research on the nucleation processes during $\mathrm{Cr}, \mathrm{Zn}, \mathrm{Cu}, \mathrm{Si}, \mathrm{Ag}$, and $\mathrm{Al}$ condensation at deposition of ultra-weak flows of magnetron sputtered substance under quasi-equilibrium conditions in deeply purified Ar. Such a broad spectrum of metals and Si has been chosen with the aim to establish the most general features of the nucleation process of quasi-equilibrium condensates. As a substrate material, fresh (001) KCl cleavages and glass were used. The structural and morphological characteristics of the obtained condensates have been studied using scanning and transmission electron microscopy. The phase composition of the condensates was studied using electron microdiffraction. The ultra-low vapor flows of ion-sputtered substance have been formed using a vacuum setup equipped with three direct current magnetron sputters. In order to form ultra-low vapor flows, increased pressures of the working gas (6-8 $\mathrm{Pa}$ ) and a large distance from the target to the substrate $(80-100 \mathrm{~mm})$ were used. The results of TEM and SEM investigations have shown that plasma action onto the (001) $\mathrm{KCl}$ surface determines the formation of a continuous amorphous film at the first stage of nucleation. As the film thickness increases, the nucleation of the crystalline phase occurs. An essential feature of the nucleation processes is the formation of the basic amorphous layer discovered in this work. An increase in the thickness of the amorphous base film reduces the effect of (001) $\mathrm{KCl}$ surface modification by plasma and local transitions to crystalline phases occur. It has been shown that a more prolonged condensation process leads to the formation of either a system of individual faceted crystals or porous nanosystems depending on the structural and morphological characteristics of the base layer.
\end{abstract}

Keywords: Magnetron sputtering, Near-equilibrium condensation, Supersaturation, Nucleation processes, Plasma-condensate system, Self-organization.

\section{INTRODUCTION}

There is a significant amount of information on changes in condensate nucleation mechanisms during the transition from large to small relative saturations $\bar{\xi}$ of the condensing vapor. It is known $[1,2]$, that at large values of $\xi$ the increased concentration of adatoms creates preconditions for their fluctuational joining into supercritical condensate nuclei. During a more prolonged condensation process, the prerequisites for the transition to a particular phase state are created in the nuclei depending on the surrounding temperature and pressure. For-example, according to the Leipunsky state diagram, a graphite-like phase is formed in supercritical carbon nuclei at relatively low ambient temperatures and pressures.

Based on theoretical works on nucleation processes at small supersaturation values [3-8], the theory of barrier nucleation was developed. In this case, the fluctuational joining of adatoms having a relatively low concentration determines the formation of subcritical nuclei. Great part of them fall apart because of increased ratio of their surface energy to volume energy. At this point, the stability of an individual nucleus is determined by its gradual growth and, as a consequence, overcoming the activation nucleation barrier $[4,6,9]$. It should be noted that the number of atoms in a nucleus at the moment of the activation barrier overcoming is $\propto 1 / \ln ^{2}(\xi+1)[4,5]$. Therefore, a decrease in $\xi$ determines an increase in critical nucleus size under
Volmer-Weber conditions and in the absence of active centers with increased adatoms desorption energy on the substrate surface.

It should be noted that, in general, continuous polycrystalline films are formed during a sufficiently long condensation process and under the above mentioned conditions of high and low supersaturations. In this case, the formation of continuous films using various PVD methods proceeds through the following stages: the coalescence of supercritical nuclei, channels formation, renucleation, and subsequent overgrowth of channels [10].The exception is structurally nonequilibrium porous condensates formed during vapor deposition under conditions of ultra-high relative supersaturation [11].

The aim of the proposed work is to study the nucleation process under conditions of ultra-low relative supersaturations in the plasma-condensate system using ion sputtering. It should be emphasized that for the vapors formed by thermal evaporation, there is an extremely low critical pressure value, below which the nucleation processes do not occur $[4,5]$. It was experimentally established that the boundary of the transition from condensate nucleation to its absence at $\xi \approx 0$ in the plasma-condensate system has a diffuse character [10], which is interesting from the fundamental and applied points of view. Under these conditions, fluctuational joining of adatoms into subcritical nuclei is an unlikely process because of their low concentration. Thus, under Volmer-Weber conditions and critically low supersaturations, individual adatoms are fixed exclu-

\footnotetext{
*ganna.korniushchenko@fulbrightmail.org
} 
sively on active centers of the growth surface for which the strongest chemical bonds are realized.

It was established $[12,13]$ that atomic selfassembling of porous nanosystems having different structural and morphological characteristics is observed under conditions of extreme approximation to thermodynamic equilibrium. It should be noted that critically low supersaturations determine the transition to the atom-by-atom condensates assembly, mainly based on kinetic processes. It is well known that, at relatively low temperatures and pressures, i.e. outside the Leipunsky phase diagram, the atomic assembly of the diamond phase and other carbon allotropes can be implemented. Our earlier research has shown [14] that the transition to the condensate atomic assembly takes place under the condition when $0<\xi<0.08$. For these reasons, the condensation under conditions of ultra-low supersaturations will be called quasi-equilibrium.

However, the amount of information on the nucleation processes in the plasma-condensate system under conditions of ultra-low supersaturation $\xi$, as a prerequisite for the further nanosystems formation, is quite limited. Therefore, the aim of the proposed work is to establish the regularities of the nucleation stage of ionsputtered $\mathrm{Cr}, \mathrm{Zn}, \mathrm{Cu}, \mathrm{Si}, \mathrm{Ag}$, and $\mathrm{Al}$ condensates under quasi-equilibrium conditions. Such a broad spectrum of metals and Si has been chosen with the aim to establish the most general features of the nucleation processes of quasi-equilibrium condensates.

\section{EXPERIMENTAL PROCEDURE}

In order to study the nucleation processes of quasiequilibrium condensates, the following technological problems should be solved:

a.

$$
\xi=\left(P_{e}-P_{o}\right) / P_{o},
$$

Taking into account (1), the pressure of the deposited vapor $P_{e}$ should be comparable with the equilibrium pressure $P_{o}$. Therefore, because majority of metals have low volatility (except $\mathrm{Zn}$ ), in order to achieve nearequilibrium conditions it is necessary to condense ultra-low vapor flows.

b. In order to achieve reproducibility of the nucleation processes under conditions of deposition of ultralow vapor flows, the technological process must be stationary.

c. The low condensate growth rates at the initial nucleation stage causes increased probability of metal and $\mathrm{Si}$ compounds formation at their interaction with chemically active residual gases. Thus, deep purification of the inert working gas (Ar) is required to avoid undesired compound formation.

d. To some extent, the nucleation process of quasiequilibrium condensates can also be affected by the contamination of the substrate surface. That is why the substrate with atomically pure surface should be used.

The ultra-low vapor flows of ion-sputtered substance have been formed using a vacuum setup equipped with three direct current magnetron sputters. It is problematic to create stationary vapor flows because at relatively low discharge powers $P_{w}$ the magnetron sputterers are, as a rule, unstable. To overcome this obstacle, slightly increased values of $P_{w}(15 \div 28 \mathrm{~W})$ were used, thus providing a stationary mode of magnetron operation. At the same time, in order to form ultra-low vapor flows, increased pressures of the working gas $\left(P_{A r}=6 \div 8 \mathrm{~Pa}\right)$ and a large distance from the target to the substrate $(L=80 \div 100 \mathrm{~mm})$ were used.

In this case, the flow of the sputtered substance to the substrate had diffusive nature and decreased to the required level due to scattering by Ar molecules. However, multiple scattering of sputtered atoms by the working gas molecules averaged their energy and provided their uniform motion in all directions with equal probability. It should be also noted that to achieve effective action of plasma onto the substrate surface, the magnetron sputterer with an unbalanced magnetic field was used.

In order to avoid impurity phases formation, the working gas deep purification was performed directly in the working chamber by titanium sputtering. The procedure of working gas purification was as follows: after pumping the working chamber, it was cut off from the pumping system and filled with argon gas up to the necessary pressure level. On the next step, long-term titanium sputtering by two lateral magnetrons was performed; titanium serves in this case as a getter pump. After the purification procedure, the chemically active gases partial pressure was about $8 \cdot 10^{-8} \mathrm{~Pa}$. At the same time, the purification procedure continued during the whole process of the condensate nucleation.

We have used C48-3 glass and fresh cleavages of $\mathrm{KCl}$ single crystals as substrates. $\mathrm{KCl}$ single crystals with dimensions of $8 \times 8 \times 20 \mathrm{~mm}$ were used. The base of such single crystals with dimensions of $8 \times 8 \mathrm{~mm}$ was rigidly attached to the substrate holder's surface. Then, at a distance of about $1 \mathrm{~mm}$ from the base of the attachment, a notch was made. On the next step, the cleavage along the notch area of (001) KCl single crystal has been performed mechanically directly inside the magnetron sputtering device using a special lever. In such a way, we have minimized the influence on the nucleation process of impurity gases adsorbed on the (001) $\mathrm{KCl}$ surface. In the case when discontinuous condensates were formed on the (001) $\mathrm{KCl}$ substrate, their fragments were fixed by additional deposition of an amorphous carbon film. In the process of TEM samples preparation, we have separated the condensates obtained from (001) $\mathrm{KCl}$ by means of dissolving the substrate in water.

Standard chemical treatment in potassium dichromate, subsequent ultrasonic cleaning and final washing in distilled water were used to clean the glass substrates from contaminants. The structure was studied by the transmission electron microscopy (TEM-125) and the scanning electron microscopy (SEM Inspect S50-B). The phase composition of the condensates was studied using electron microdiffraction.

\section{RESULTS AND DISCUSSION}

In the first set of the experiments, the nucleation stage of $\mathrm{Al}$ condensates on (001) $\mathrm{KCl}$ cleavages has been investigated. For this series of experiments, the following technological parameters were used: $T_{c}=280^{\circ} \mathrm{C}, L=80 \mathrm{~mm}, P_{\mathrm{Ar}}=8 \mathrm{~Pa}, P_{w}=16 \mathrm{~W}$, and the deposition time $\left(t_{c}\right)$ for different stages of nucleation 
varied from 0.05 to $0.38 \mathrm{~h}$. It should be noted that $\mathrm{Al}$ condensates were not additionally fixed by an amorphous carbon film.

From TEM images of microstructures and corresponding electronograms (Fig. 1a, b), it can be concluded that an amorphous continuous $\mathrm{Al}$ film was formed at the initial stage of condensation. At the same time, further condensation determines the nucleation of crystals corresponding to the aluminum fcc phase (see Fig. 1c, d). It should be noted that the transition to the crystalline phase most likely occurred on the surface of the amorphous phase. The latter conclusion is confirmed by the absence of the orienting effect of (001) $\mathrm{KCl}$ on the crystal growth, which can be explained by the presence of amorphous layers between the $\mathrm{Al}$ crystals and the substrate.

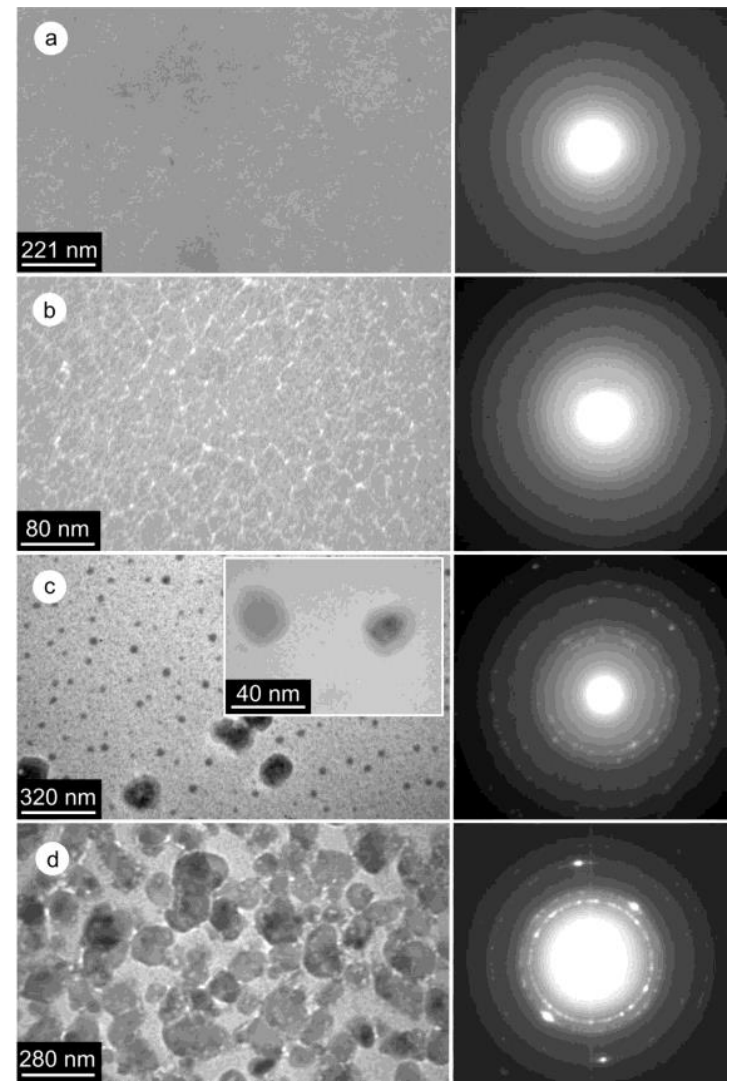

Fig. 1 - TEM investigations of $\mathrm{Al}$ condensates obtained on $(001) \mathrm{KCl}$ cleavages and the corresponding electron diffraction patterns of the nucleation stage under conditions: $T_{c}=280{ }^{\circ} \mathrm{C}$, $L=80 \mathrm{~mm}, P_{\mathrm{Ar}}=8 \mathrm{~Pa}, P_{w}=16 \mathrm{~W}$ and deposition time: (a) $t_{c}=0.05 \mathrm{~h}$, (b) $t_{c}=0.08 \mathrm{~h}$, (c) $t_{c}=0.28 \mathrm{~h}$, (d) $t_{c}=0.38 \mathrm{~h}$

Figs. 2a, b show SEM images of the $\mathrm{Al}$ condensates structure, which was formed on the glass substrate using technological conditions of the condensation process identical to the previous experiment. Due to the difficulty of separating the condensate from the glass, the presence or absence of the basic amorphous phase has not been established. At the same time, at the nucleation stage, crystals are formed at a rather limited number of active centers (Fig. 2a). As a result, after a fairly long deposition $\left(t_{c}=3 \mathrm{~h}\right)$, there is outpacing growth of unconnected faceted crystals up to $20 \mu \mathrm{m}$ in size (see Fig. 2b).

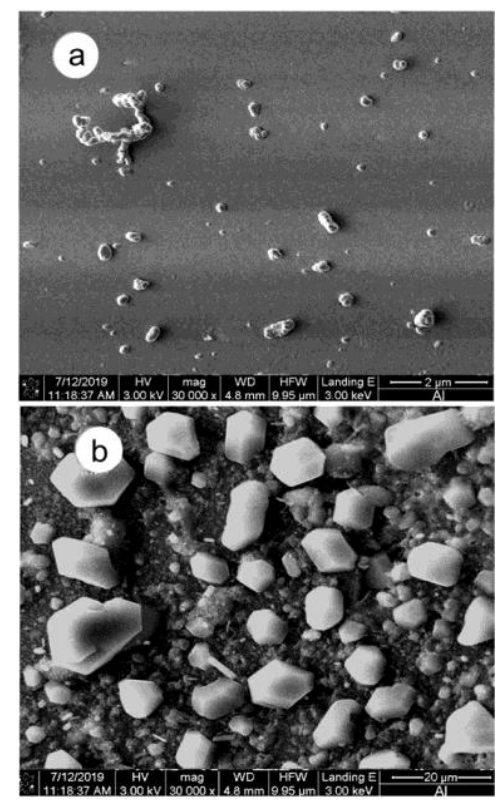

Fig. 2 - SEM images of Al structures obtained on glass substrates at $T_{c}=280^{\circ} \mathrm{C}, L=80 \mathrm{~mm}, P_{\mathrm{Ar}}=8 \mathrm{~Pa}, P_{w}=16 \mathrm{~W}$ and deposition time: (a) $t_{c}=0.05 \mathrm{~h}$, (b) $t_{c}=3 \mathrm{~h}$

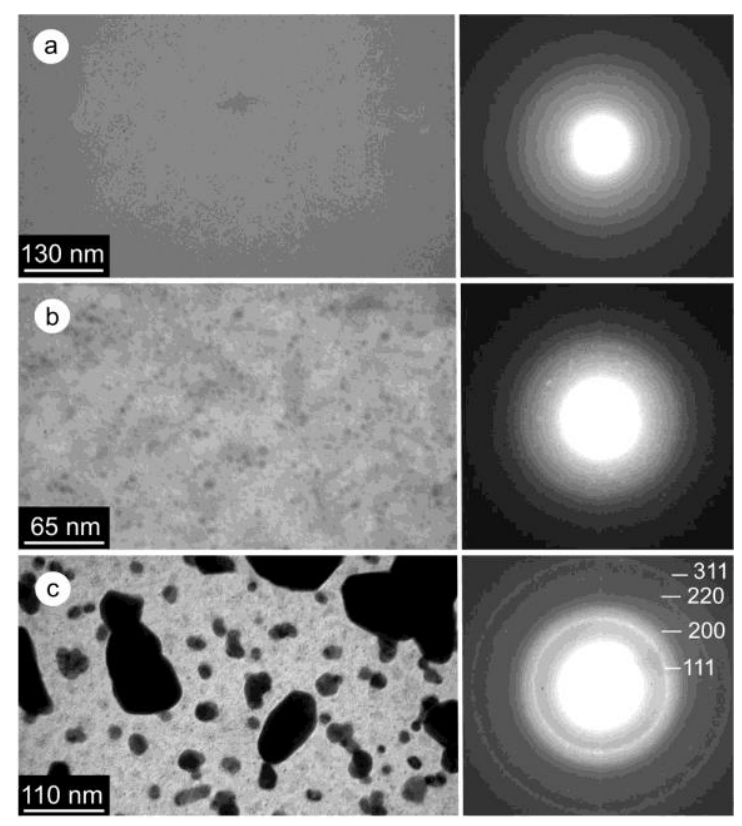

Fig. 3 - TEM images of structures and corresponding electrograms of $\mathrm{Ag}$ condensates obtained on (001) $\mathrm{KCl}$ cleavages under conditions $T_{c}=280^{\circ} \mathrm{C}, L=80 \mathrm{~mm}, P_{\mathrm{Ar}}=6 \mathrm{~Pa}, P_{w}=15 \mathrm{~W}$ and deposition time: (a) $t_{c}=0.017 \mathrm{~h}$, (b) $t_{c}=0.03 \mathrm{~h}$, (c) $t_{c}=0.06 \mathrm{~h}$

The results of TEM studies of Ag condensates at different stages of their nucleation and the corresponding electrograms are shown in Fig. 3. Since the separation of condensates from (001) KCl was carried out without prior application of a carbon film, it can be concluded that a basic amorphous layer also formed at the first stage of nucleation (Fig. 3a). In this case, as the thickness of the amorphous layer increases, a gradual transition to the crystalline state occurs (Fig. 3b). The absence of the crystalline phase nucleation texture confirms the presence of the basic amorphous layer between the crystals and the substrate, which with an increase in the 
layer thickness gradually transforms into a fine polycrystal. Further growth of the condensates, as well as in the case of $\mathrm{Al}$ condensates formation, is characterized by well-defined anticipatory growth of individual crystals with the fcc lattice of Ag (Fig. 3c).

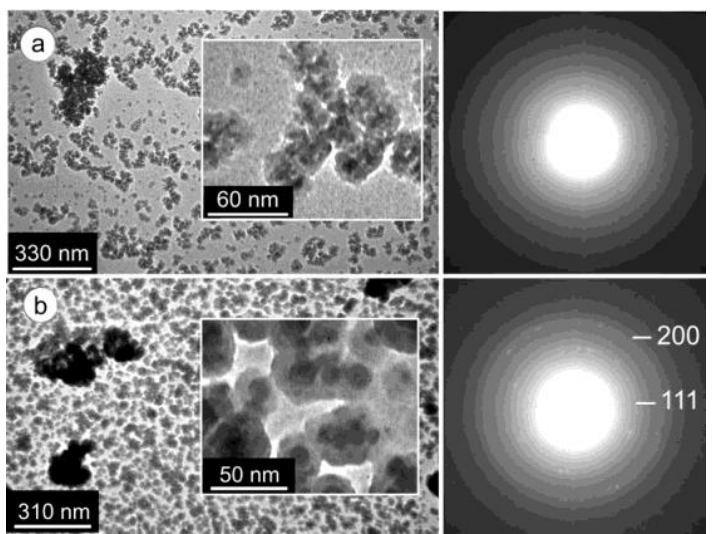

Fig. 4 - TEM images of structures and corresponding electrograms of $\mathrm{Si}$ condensates obtained on (001) KCl under conditions $T_{c}=280^{\circ} \mathrm{C}, L=90 \mathrm{~mm}, P_{\mathrm{Ar}}=6 \mathrm{~Pa}, P_{w}=30 \mathrm{~W}$ and deposition time: (a) $t_{c}=0.2 \mathrm{~h}$, (b) $t_{c}=0.25 \mathrm{~h}$

Fig. 4 presents TEM images of structures and electrograms of $\mathrm{Si}$ condensates obtained at $T_{c}=280^{\circ} \mathrm{C}$, $L=90 \mathrm{~mm}, P_{\mathrm{Ar}}=6 \mathrm{~Pa}$ and $P_{w}=30 \mathrm{~W}$. It should be noted that the attempt to separate $\mathrm{Si}$ condensate in the form of the amorphous phase only from (001) $\mathrm{KCl}$ was unsuccessful. That is why we have investigated Si condensates formed during a more prolonged nucleation process with the thickness value that could withstand the separation procedure. Despite this, the significant diffusion scattering of electrons and weak diffraction rings in the background (Fig. 4) that are present on the electrograms evidence with a high probability the presence of a basic amorphous layer.
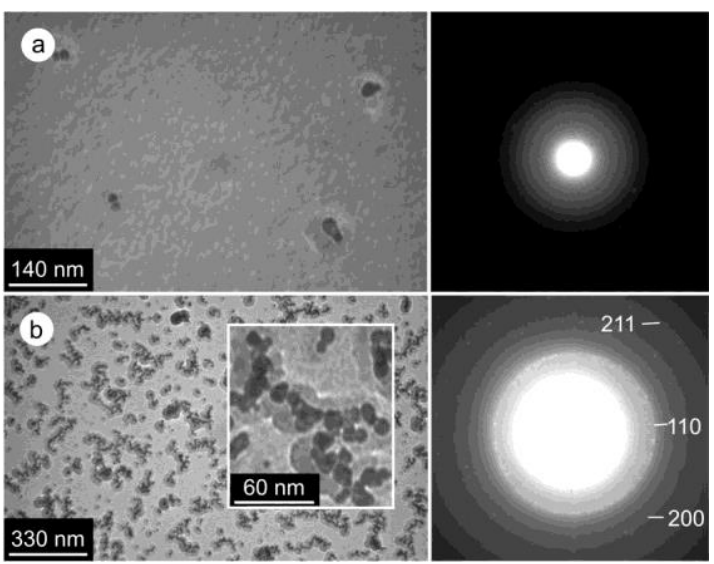

Fig. 5 - TEM images of structures and corresponding electrograms of $\mathrm{Cr}$ condensates obtained on (001) $\mathrm{KCl}$ substrates under conditions $T_{\mathrm{c}}=280^{\circ} \mathrm{C}, L=100 \mathrm{~mm}, P_{\mathrm{Ar}}=8 \mathrm{~Pa}, P_{w}=15 \mathrm{~W}$ and deposition time: (a) $t_{c}=60 \mathrm{~s}$, (b) $t_{c}=150 \mathrm{~s}$

In this case, the calculated interplanar distances based on diffraction maxima with indices 111 and 200 satisfactorily coincide with the corresponding Si interplanar distances.

The presence of a basic amorphous layer was also established during the condensation of $\mathrm{Cr}$ vapor at the following technological parameters: $T_{c}=280^{\circ} \mathrm{C}$, $L=100 \mathrm{~mm}, P_{\mathrm{Ar}}=8 \mathrm{~Pa}$ and $P_{w}=15 \mathrm{~W}$ (Fig. 5a). As in the previous cases, with an increase in thickness of the amorphous layer, the formation of individual crystals occurs first, which stimulates further nucleation and growth of other crystals in the vicinity to the primary ones (Fig. 5b). At the end, let us consider examples of nucleation of $\mathrm{Zn}$ and $\mathrm{Cu}$ quasi-equilibrium condensates on glass substrates. From SEM images shown in Fig. 6 it can be concluded that the nucleation processes of zinc condensates are characterized by the formation of crystals with a well-defined facets. In this case, the predominant growth of individual crystal nuclei in one of the crystallographic directions and their intergrowth with each other during a long-term technological process leads to the formation of nanosystems in the form of three-dimensional layers [15].

Also noteworthy is the predominant growth of structural formations based on interconnected $\mathrm{Zn}$ nanocrystals (Fig. 6a). The nucleation processes of copper quasi-equilibrium condensates onto the glass are also characterized by the discontinuous structures formation and growth of individual nuclei with different rate (Fig. 6b). In this case, on the substrate surface, separate nanoparticles with sizes smaller than $100 \mathrm{~nm}$ are formed (Fig. 6b) as in the previous cases.

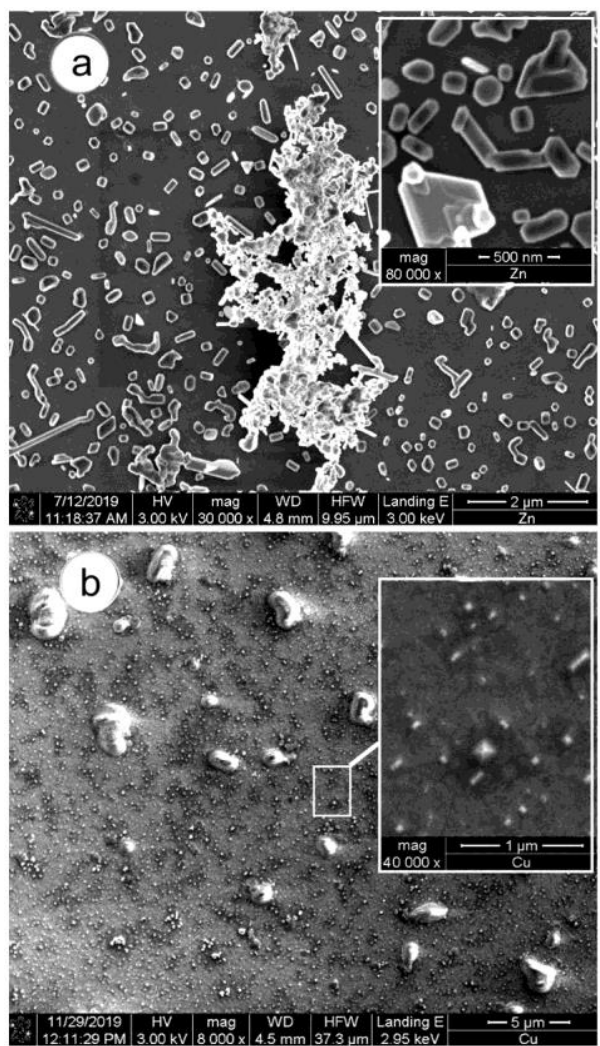

Fig. 6 - SEM images of $\mathrm{Zn}$ (a) and $\mathrm{Cu}$ (b) structures obtained on glass substrates at $T_{c}=280^{\circ} \mathrm{C}, L=80 \mathrm{~mm}, P_{\mathrm{Ar}}=8 \mathrm{~Pa}$ and $P_{w}=16 \mathrm{~W}\left(t_{c}=0.08 \mathrm{~h}\right.$ for $\left.\mathrm{Zn} ; t_{c}=0.05 \mathrm{~h} \mathrm{for} \mathrm{Cu}\right)$

It is known [16] that the energy of ion-sputtered atoms, even after their thermalization at high pressures of the working gas, can be one order of magnitude higher than the energy of thermally evaporated atoms. The action of high-energy plasma particles onto the 
substrate surface and the subsequently formed condensate determines a whole set of physical processes. Thus, one of the crucial factors influencing the nucleation processes is the additional heating of the substrate surface and the growth surface, which brings the plasma-condensate system closer to thermodynamic equilibrium. The increased energy of condensing atoms together with the possibility of direct energy transfer from plasma particles to adatoms causes a reduction of the average desorption energy of adatoms $E_{d}$ to some sufficient value $E_{d e f}[12]$. This decrease in the desorption energy will stimulate an increase in the equilibrium pressure $P_{o}$ and, according to (1), reduce the relative supersaturation $\xi$. In other words, the action of plasma on the substrate surface allows the condensates formation with low volatility under conditions close to thermodynamic equilibrium. For obvious reasons, this factor is one of the determinants in the physical processes of nucleation of quasi-equilibrium condensates.

An essential feature of the nucleation processes is the formation of a basic amorphous layer discovered in this work. To explain the effect of the amorphous phase formation, let us consider the model representations of this process, which is presented in Fig. 7.

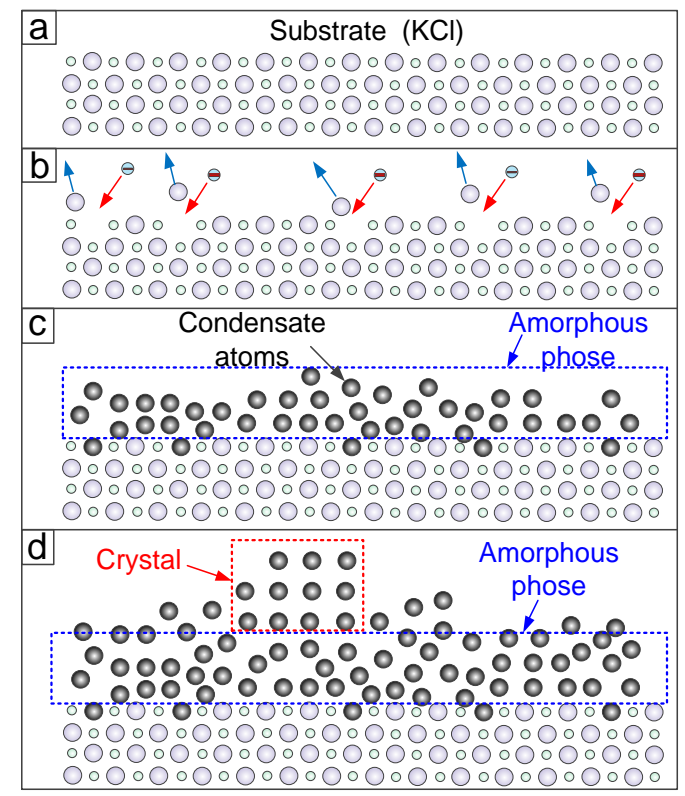

Fig. 7 - Model representation of the nucleation stages of quasiequilibrium condensates on (001) $\mathrm{KCl}$ substrate in the plasmacondensate system

At the first stage of nucleation on atomically pure $\mathrm{KCl}$ surfaces (Fig. 7a), surface defects in the form of anionic vacancies $\mathrm{Cl}^{-}$are created under the action of secondary electron fluxes of the magnetron sputterer and plasma (Fig. 7a). The first condensate atoms are fixed at the created active centers. At the next stage, due to the realization of rather strong chemical bonds between a fixed condensate atom on the $\mathrm{Cl}^{-}$vacancy and other adatoms, a continuous amorphous layer is formed (Fig. 7c). Most likely, the amorphization of the base layer is partly determined by the short life time of the adatoms on the substrate surface, which is natural for quasi-equilibrium condensation and does not allow the formation of the most structurally equilibrium crystalline phase. On the other hand, the amorphization process is stimulated by the symmetry of atoms that are rigidly fixed on $\mathrm{Cl}^{-}$vacancies, which does not coincide with the symmetry necessary to create the crystalline phase.

It should be noted that in this case, the most highenergy atoms of the condensed substance can be implanted into the top surface layer of (001) KCl or glass substrate destroying in such a way (001) $\mathrm{KCl}$ surface and leading to pseudomorphic growth of the metastable amorphous phase. To some extent, the above mentioned process is confirmed by the absence of orienting action of (001) $\mathrm{KCl}$ on growing nuclei, that we can see from the absence of any texture of crystal nucleation.

As shown in Fig. 1c, Fig. 3b and Fig. 5a, an increase in the thickness of an amorphous base film reduces the effect of (001) KCl surface modification by plasma and, as a consequence, local transitions to crystalline phases occur (Fig. 7d). In this case, local crystallization with the release of energy stimulates crystallization in the areas adjacent to the primary crystals, forming in such a way a branched system of adjacent crystals (Fig. 4 and Fig. 5b). Subsequent condensation can lead to a completely natural growth of individual crystals with different rates (Fig. 2b, Fig. 3c, and Fig. 6). In other cases or when the surface density of primary crystalline nuclei satisfies the inequality [22]

$$
\left[\pi\left(\bar{r}+\lambda_{i}\right)^{2}\right]^{-1}<n_{i}<\left(\pi \bar{r}^{2}\right)^{-1}
$$

where $\lambda_{i}$ is the diffusion path length of the adatoms, $\bar{r}$ is the average radius of nuclei with surface concentration $n_{i}$, the effect of Ostwald ripening can be observed.

Of interest from a practical point of view should be the case of nanosystems formation, provided that the density of surface crystalline nuclei is high enough and, accordingly, there is a partial overlapping without the classical variant of coalescence (Fig. 1d). In this case, the preconditions for the further formation of various porous nanosystems are created $[12,14,15]$.

It should also be noted that the formation of fairly thin solid amorphous metal films also has some practical significance. The technological approach presented in this work can be used in the development of such devices as solar energy converters, functional materials based on plasmon resonance, various types of sensors [18-20].

\section{CONCLUSIONS}

1. First of all, from the above experimental results, we can conclude significantly different mechanisms of nucleation of quasi-equilibrium condensates in plasmacondensate system and during the deposition of thermally evaporated vapors without plasma. The main differences between the nucleation mechanisms are determined by the action of high-energy plasma particles onto the substrate surface in the case of plasmacondensate system. These high-energy particles include secondary electrons of the magnetron sputterer and plasma, atoms and ions of the working gas, as well as atoms and ions of sputtered metals or $\mathrm{Si}$.

2 . The well-known ideas about the formation of nonporous films by the condensation of low-volatile metals under Volmer-Weber conditions correspond to usage of 
sufficiently high supersaturations. On the other hand, quasi-equilibrium self-assembly allows obtaining porous low-dimensional systems of nanocrystals. Moreover, during the condensation under near thermodynamic equilibrium, nucleation processes have significant differences from traditional ideas about the condensation of ion-sputtered matter. These include experimentally established growth of a metastable amorphous phase under the plasma action onto the growth surface. As the layer thickness increases, the transition from the amorphous phase to the crystalline phase formation occurs.

3. Further condensation leads to a growth of individual crystals with different rates and, as a result, promotes the formation of porous nanosystems having various structural and morphological characteristics. A decisive role in the formation of porous nanosystems is played by the processes associated with the reorientation of the condensed flow to the areas of the primary cluster accumulation, as well as homogeneous nucleation at the sites of their intergrowth in the absence of the classical variant of coalescence.

\section{ACKNOWLEDGEMENTS}

This work was supported by the Ministry of Education and Science of Ukraine within the research grant «Peculiarities of $\mathrm{ZnO}, \mathrm{C}, \mathrm{C} / \mathrm{ZnO}$ and $\mathrm{ZnO} / \mathrm{NiO}$ nanoporous layers formation for potential application as electrodes in Li-ion batteries», the project number $0119 \mathrm{U} 100763$.

\title{
REFERENCES
}

1. A.V. Osipov, J. Phys. D.: Appl. Phys. 28, 1670 (1995).

2. V.G. Dubrovskii, Physica A 308, 192 (2002).

3. A.A. Chernov. E.I. Givargizov, K.S. Bagdasarov, V.A. Kuznetsov, L.N. Demianets, A.N. Lobachev, Modern Crystallography III (Springer: 1984).

4. S.A. Kukushkin, A.V. Osipov, Sov. Phys. Usp. 41 No 10, 1083 (1998).

5. D. Walgraef, Physica E 18, 393 (2003).

6. D. Du, D.J. Srolovitz, J. Cryst. Growth 296, 86 (2006).

7. S.A. Kukushkin, A.V. Osipov, Prog. Surf. Sci. 51, 1 (1996).

8. A. Galdikas, Appl. Surf. Sci. 254, 3964 (2008).

9. M.P. Anisimov, Russ. Chem. Rev. 72, 591 (2003).

10. Handbook of Thin Film Technology, Vol. 2 (Ed. by L.I. Maissel, R. Glang) (McGraw-Hill, 1970).

11. A. Anders, Thin Solid Films 518, 4087 (2010).

12. V.I. Perekrestov, Yu.O. Kosminska, A.S. Kornyushchenko, V.M. Latyshev, J. Porous Mater. 21 No 6, 1159 (2014).

13. V.I. Perekrestov, Yu.O. Kosminska, A.S. Kornyushchenko, V.M. Latyshev, Physica B: Condens. Matter. 411, 140 (2013).

14. V.I. Perekrestov, A.I. Olemskoi, Yu.O. Kosminska, A.A. Mokrenko, Phys. Lett. A 373 No 37, 3386 (2009).

15. A.S. Kornyushchenko, A.H. Jayatissa, V.V. Natalich, V.I. Perekrestov, Thin Solid Films 604, 48 (2016).

16. Y.V. Martynenko, A.V. Rogov, V.I Shul'ga, Tech. Phys. 57 No 4, 39 (2012).

17. W.H. Qi, B.Y. Huang, M.P. Wang, Z. Li, Z.M. Yu, Phys. Lett. A. 370, 494 (2007).

18. J.van Deelen, A. Illiberi, A. Hovestad, I. Barbu, L. Klerk, Proc. SPIE 8470, 84700 (2012).

19. N. Ahmad, J. Stokes, N.A. Fox, M. Teng, M.J. Cryan, Nano Energy 1, 777 (2012).

20. P. Berini, Adv. Opt. Photon. 1, 484 (2009).

\section{Етапи нуклеації квазірівноважних конденсатів іонно розпилених атомів $\mathrm{Cr}, \mathrm{Zn}, \mathrm{Cu}, \mathrm{Si}, \mathrm{Ag}$ та $\mathrm{Al}$}

\author{
Г.С. Корнющенко, Ю.О. Космінська, С.Т. Шевченко, В.В. Наталіч, В.І. Перекрестов
}

\section{Сумський державний університет, вул. Рилського-Корсакова, 2, 40007 Сули, Украӥна}

\begin{abstract}
У статті представлені результати досліджень етапів нуклеації конденсатів $\mathrm{Cr}, \mathrm{Zn}, \mathrm{Cu}, \mathrm{Si}, \mathrm{Ag}$ та $\mathrm{Al}$ при осадженні надслабких потоків розпиленої магнетроном речовини в квазірівноважних умовах в глибоко очищеному Ar. Досліджений в роботі розширений спектр металів та Si обумовлений необхідністю встановлення найбільш загальних особливостей процесу нуклеації квазірівноважних конденсатів. Як матеріал підкладки використовували свіжі сколи (001) $\mathrm{KCl}$ та скло. Структурно-морфологічні характеристики отриманих конденсатів вивчені за допомогою скануючої та просвічуючої електронної мікроскопії. Фазовий склад конденсатів вивчався за допомогою мікродифракції електронів. Для формування надслабких парових потоків іоннорозпилених металів та $\mathrm{Si}$ використана вакуумна установка з робочою камерою, що укомплектована трьома магнетронними розпилювачами на постійному струмі. Наднизькі парові потоки, що приймали участь в нуклеації, формувалися за рахунок підвищених тисків робочого газу (6-8 Па) та відстані від мішені до підкладки (80-100 мм). На основі просвічуючої та растрової електронної мікроскопії встановлено, що дія на поверхню (001) $\mathrm{KCl}$ часток плазми на першому етапі нуклеації визначае формування суцільної аморфної плівки, з ростом товщини якої відбувається зародження кристалічної фази. Важливою особливістю процесів нуклеації є виявлене в роботі формування базового аморфного прошарку. При збільшенні товщини аморфної базової плівки знижуеться вплив модифікованої плазмою поверхні (001) $\mathrm{KCl}$ на процес аморфізації, i, як наслідок, відбуваються локальні переходи до кристалічної фази. Показано, що залежно від структурноморфологічних характеристик базового шару нанокристалів при подальшій конденсації може формуватися система окремих огранених кристалів або пористі наносистеми.
\end{abstract}

Ключові слова: Магнетронне розпилення, Квазірівноважна конденсація, Пересичення, Процеси нуклеації, Плазма-конденсат, Самоорганізація. 